\title{
Effective Strategy for Succession Planning in Higher Education Institutions
}

\author{
Abd Rahman Ahmad ${ }^{\star \rtimes}$ (D) \\ Tan Zan Ming' ${ }^{2}$ \\ Hairul Rizad Md Saprys
}

${ }_{1,2}$ Faculty of Technology Management and Business, Universiti Tun Hussein Onn, Malaysia, Johor, Malaysia.

Email:arahman@uthm.edu.mvTel:+6074533982

Email:mankuittho@yahoo.com

${ }^{s}$ Universiti Kuala Lumpur, Kuala Lumpur, Malaysia

${ }^{s}$ Email:hairulrizad@unikl.edu.my

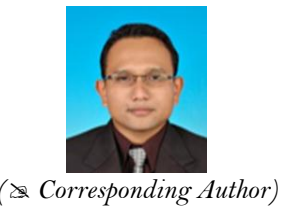

( Corresponding Author)

\begin{abstract}
Succession planning could ensure leadership continuity in an organization. Organizations start to realize the importance of strong leadership to maintain, grow, and sustain long-term business productivity. The semi-structured interview which lasts for thirty to forty minutes was used as the interview technique throughout this research because the semi-structured interview is more conversational and it also allowed the researcher to ask the questions in a more flexible way. The interview method found out the systematic succession planning system in University A. The primary data was from interviews that shows the systematic succession planning in University A, and the gathered data will show some of the practices. Overall, the succession planning management had followed up the seven-pointed model as proposed by Rothwell. The sevenpointed model as proposed by Rothwell had ensured the process of identifying a management position at the selected university. In this study, the research objective and research question has been answered by the researcher. The final results further explained the process of succession planning together with the recommendation of the study. Future research on succession planning in higher education can be improved to get better research results as if the data collection can be expanded to all levels of management in University A, as compared to this research which only covered the staff involved in the strategic position level.
\end{abstract}

Keywords: Succession planning, Higher education, Public University, Strategic position, Key positions, Leadership.

Citation | Abd Rahman Ahmad; Tan Zan Ming; Hairul Rizad Md Sapry (2020). Effective Strategy for Succession Planning in Higher Education Institutions. Journal of Education and e-Learning Research, 7(2): 203-208.

History:

Received: 27 April 2020

Revised: 3 June 2020

Accepted: 1 July 2020

Accepted: 1 July 2020

Licensed: This work is licensed under a Creative Commons

Attribution 3.0 License (cc) E

Publisher: Asian Online Journal Publishing Group
Acknowledgement: All authors contributed to the conception and design of the study.

Funding: The authors would like to thank you to Research Management Office (RMC), Universiti Tun Hussein Onn Malaysia for allowed this paper to be presented by covering fees by using research fund (E15501) UTHM. Competing Interests: The authors declare that they have no conflict of interests.

Transparency: The authors confirm that the manuscript is an honest, accurate, and transparent account of the study was reported; that no vital features of the study have been omitted; and that any discrepancies from the study as planned have been explained.

Ethical: This study follows all ethical practices during writing.

\section{Contents}

1. Introduction

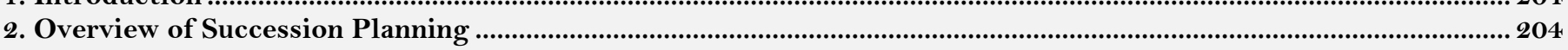

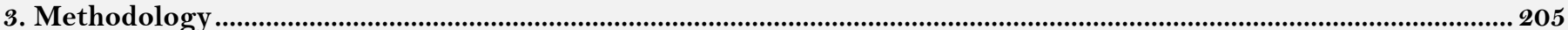

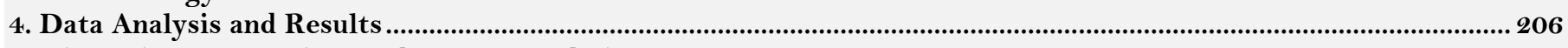

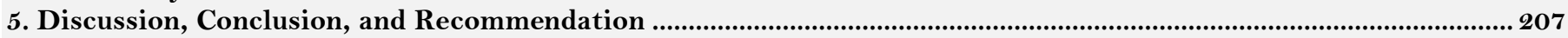

References. 


\section{Contribution of this paper to the literature}

This study contributes to the existing literature by exploring the process of succession planning at higher education institutions in Malaysia. Results indicated that autonomy to the higher education institutions has the crucial factors to the implementation of succession planning. Here, higher education institutions with full autonomy will be more flexible in implementing the program.

\section{Introduction}

Succession planning is a long term preparation process for developing replacements for the key positions to ensure continuing leadership in an organization (Jamye, Johnson, Faught, \& Street, 2013). The probability of both short-term and long-term leadership continuity in an organization can be increased if the organization has established a systematic and effective succession planning (Thompsen, Joyce, \& Smith, 2006). Nowadays, higher education institutions are facing an impending leadership crisis, which is the lack of a future leader, and they need to have a formal succession planning to ensure their organizational leadership continuity in the future (Ahmad \& Keerio, 2020; Barden, 2009).

\section{Overview of Succession Planning}

Rothwell (2005) had introduced a succession planning model. In the model, seven steps for systematic succession planning and management had been identified, which were to commit, assess present work, appraisal individual performance, assess future work, assess future individual potential, close the development gap, and evaluate the succession planning program. In his model, he mentioned that promotion from within the organization is very important because, for the succession planning to be effective, the organization must have some means by which to replace key job incumbents as vacancies occur in their positions.

Promotion from within also provides some benefits. First, the employer can check the references of existing employees easily. Second, the cost of promoting from within an organization is often lower than hiring from outside (Rothwell, 2005). However, more than $37 \%$ of the Fortune 1,000 companies in the USA are run by external recruits (2004). 55\% of outsider CEOs who left their positions in 2003 were forced to resign by their boards as compared to 34 percent of the insiders.

We are seeing a trend, in which an organization is more likely to recruit talent from outside rather than within according to Rao and Drazin (2002). Fancher (2007) suggested that a company that fails to grow its successors needs to recruit people from the outside. After interviewing some chief human resources officers (CHROs), Pitman (2000) suggested that administrative staff in higher education have a lower priority than faculty and students, and this results in the widespread use of external hiring, rather than the development of the internal candidate. It has been suggested that external hiring is superior to internal hiring because it provides HEIs a chance to achieve what they cannot through internal development. However, conducting an open search to fill leadership positions also has the risk of disenfranchising worthy internal candidates (Barden, 2009; Gonaim, 2019; Kamal, 2019; Keller, 2018). It is important to identify the situation that is best used for internal or external recruitment.

\subsection{Definition of Succession Planning}

Succession planning is a process of identifying critical management positions. It can start at the levels of a project manager, supervisors, and up to the highest position in the organization (Rothwell, 2005). Succession planning is a proactive process that ensures continuing leadership committed to the organization's value, mission, and strategies plan by intentionally developing employees within the organization for advancement (Jamye et al., 2013).

\subsection{Origins of Succession Planning}

One of the earliest scholars to mention the advantages of succession planning was Henri Fayol. Henri Fayol believe that succession planning can help to avoid organizational missteps because succession planning ensures putting the right people in the right positions at the right time.

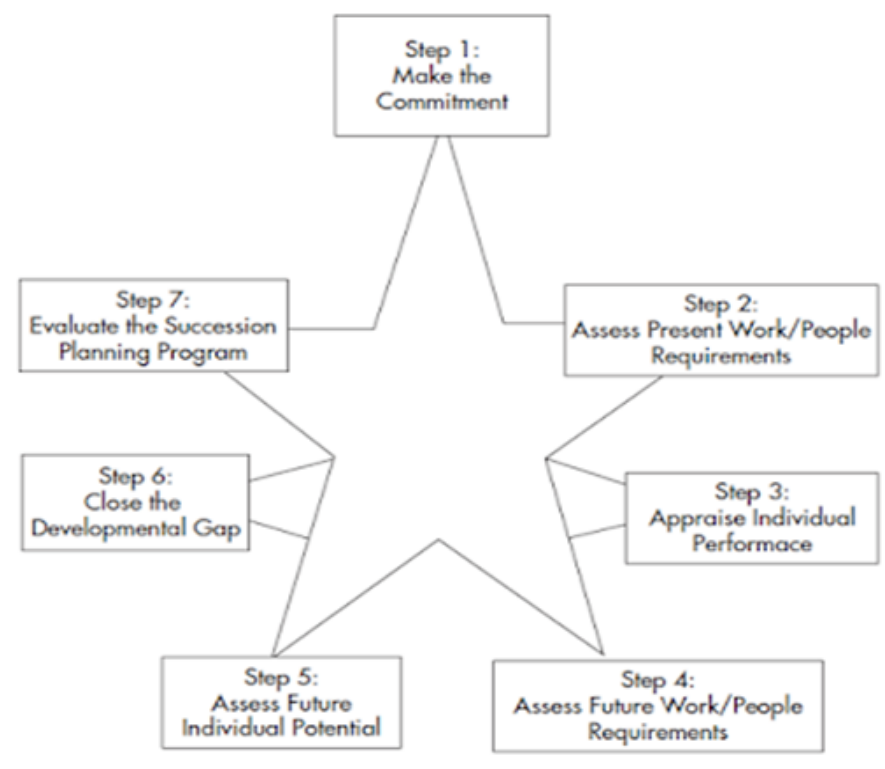

Figure-1. Rothwell's seven-pointer star model. Source: Rothwell (2010). 
Succession planning is important for an organization because every organization needs to invest in training and develop an individual so that he or she would be well equipped and has the qualifications to take over any leadership position as shown in Figure 1.

\section{Methodology}

In this session, the methodology conducted in this research will be explained in detail. The research methodology is an element used to ensure that the way to collect data will achieve the objectives of the research within the specified scope. The type of data collection method, the data collection technique, and the data analysis technique will be discussed. In order to do proper research, the methodology must be clear so that the data collected will be accurate and precise. In this case, this research will adopt a case study research method to achieve the set research objectives.

Qualitative methodology was chosen because the information required in this research would not be in the quantitative or numeric form and opinions and experience from the respondents were necessary. The qualitative approach enables the researcher to read and engage with information critically, and also refine the essence from the large body of information (Braun \& Clarke, 2013).

\subsection{Sample and Population}

Purposive sampling method was used in this research. The criteria used in the selection of the sample included academic and non-academic staff who are involved in the systematic succession planning program in University A. The target population was drawn from the range of academic staff to non-academic staff in the related department. The size of the research sample was targeted at four participants who were randomly selected from the target population.

\subsection{Research Instrument}

The semi-structured interview which lasts for thirty to forty minutes was used as the interview technique throughout this research because the semi-structured interview is more conversational and it also allowed the researcher to ask the questions in a more flexible way. The interview method covered the systematic succession planning system in University A. The primary data was from an interview with the selected individual. The interview showcased the systematic succession planning in University A, and the gathered data showcased some of the practices.

Meanwhile, the interview process involved several stages. First, the researcher had drafted the interview questions based on the research questions that need to be determined. Second, the researcher started to contact each individual. Electronic mail was sent by the researcher to each individual to request the implementation of the interview, or phoned those individuals, who did not reply to the researcher by electronic mail. After the confirmation of the interview by the respondents, the researcher started to interview the respondents according to the agreed date, time, and venue. The interviewer asked the interviewee permission to record the whole interview session in the audio form for further review.

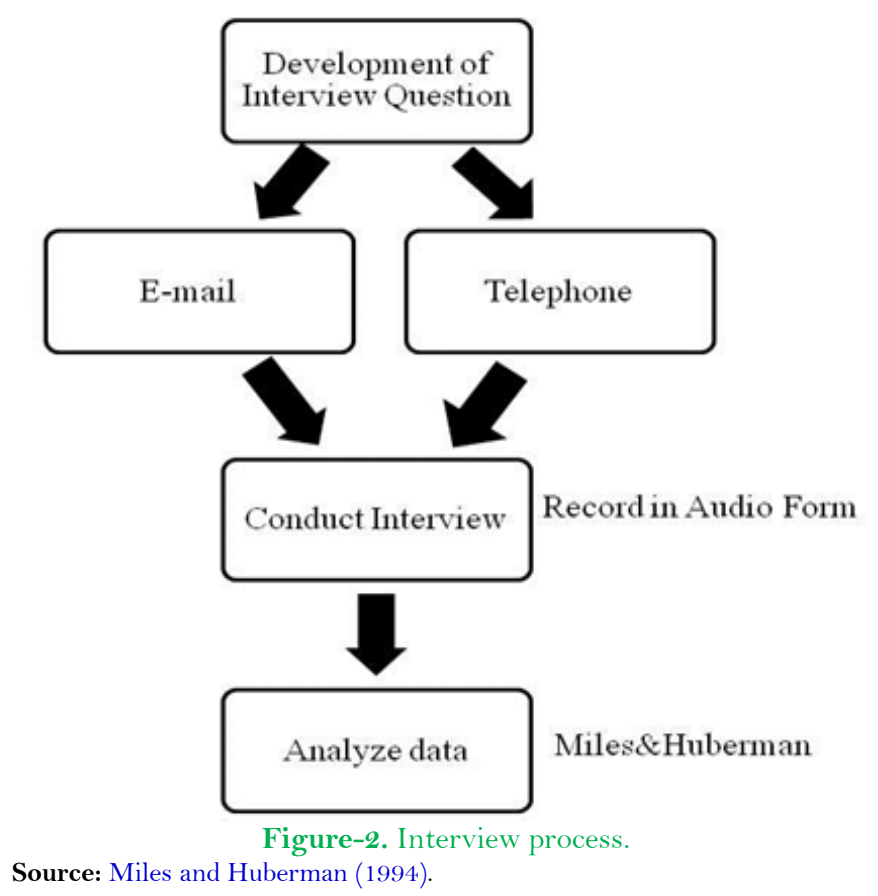

Lastly, the interview data was analyzed by the researcher through the interactive model proposed by Miles and Huberman (1994) as shown in Figure 2.

\subsection{Data Analysis}

The Miles and Huberman (1994) framework will be used for data analysis for this study. The analysis contains three main components. First, data reduction occurred in different stages through editing, summarizing the data, coding and conceptualizing, and explaining. The data collected was organized, focused, discards, and sorts systematically. Hence, by using the data reduction analysis, it helped to reduce the data without any significant loss of information. Data displays helped to organize compress and assemble information. It is important to display data in the correct way to validate the analysis. Data in the forms of graph, charts, and diagram was displayed for further analysis. Drawing conclusions logically will follow the reduction and display of data. A possible conclusion 
may be noted early in the analysis however data was integrated from data reduction and data displays analysis again for drawing conclusions and verification.

\section{Data Analysis and Results}

The raw data was recorded in audio form and further processed into useful information to answer the research question in this research study. The objective of this section was to identify the systematic succession planning program process carried out by University A to ensure the continuity of leadership. An analysis of the findings was provided in eight criteria.

Most of the respondents agreed that the commitment level in University A was very high. All the academician and administrator staffs showed a positive attitude toward the succession planning program implemented in University A. The succession planning is very important as it can groom their successor to be more effective, and to ensure the leadership continuity in University A.

\subsection{Job Position Involved in Succession Planning}

Both the academic and administration staff have the opportunity to be involved in the succession planning program in University A. The strategic position in University A can be divided into three categories. The first category involved the chancellor and the deputy chancellor. The second category involved the dean, deputy dean, director, and head of the department, while the third category involved the officer and professional with designation or grade of 48 and above. The succession planning in University A has only targeted the staff from Category 2 and Category 3, while the selection of Category 1 is done by the government as indicated in Table 3.

Table-3. Job Position involved.

\begin{tabular}{c|l}
\hline Respondents & Job position \\
\hline A & Strategic position \\
\hline B & Grade 48 and above \\
\hline C & Not involved. \\
\hline D & Not involved. \\
\hline
\end{tabular}

\subsection{Performance Appraisal}

In order to be in the candidate pool list, the staff must reach high achievement in their annual evaluation appraisal as stated in Table 4. They must also not be in the legal dispute with University A. Senior working experience is needed.

\begin{tabular}{c|l}
\multicolumn{2}{c}{ Table-4. Performance appraisal. } \\
\hline Respondents & Criteria used \\
\hline A & Annual evaluation $>85 \%$, not disputation. \\
\hline B & Yearend appraisal $>85 \%$. \\
\hline C & Senior, experience. \\
\hline D & Achieved the set standard. \\
\hline
\end{tabular}

\subsection{Training in Related Key Position}

Both the AKEPT and the university will provide training to those who involved in the succession planning program. AKEPT serves to create a transformation in Malaysia's higher education, to organize training programs in leadership, learning, and teaching, research, and innovation for numerous top senior officers, middle management officers, and academicians of the higher education institution.

\subsection{Assessment of Individual Potential}

Overall, the respondents agreed that the dope personality test, which categorizes candidates into four categories, that is the dove, owl, peacock, and eagle, is still a useful test to determine the potential of a candidate to be a leader. More of the strategically positioned staff belong to the eagle category because the eagle has leadership traits such as highly analytical and decisive.

\subsection{Internal Candidate}

The priority to fill in the key vacant position will only be given to the internal or existing staff because the decisionmaking position requires working experience. The possibility to find an outside candidate to fill in a vacant strategic position is very rare. The faculty member will always nominate their members to fill in the vacant key position.

\subsection{External Candidate}

The key vacant position will only be given to the existing staff, where the policy of University A prefers promotion from within rather than recruitment from outside. They will only recruit outside candidates when there is a post with a special job specification.

\subsection{Improvement for Succession Planning}

In University A, most of the respondents agreed that succession planning still hasn't reached a satisfactory level. Some improvement is needed for succession planning. Some improvement is already implemented. For example, University A had formed a new division, which is Integrity and succession planning division, under the Registrar department. This division will focus on the task to get the most suitable candidate to fill in the key vacant position, while the human resource development will focus on the task to provide training to the potential candidate pool. 


\section{Discussion, Conclusion, and Recommendation}

One way to ensure the succession planning program to be carried out smoothly is to follow the seven-pointed star model for systematic succession planning and management proposed by Rothwell (2005). Shadi and Noor (2011) also agreed on the importance and benefit of this model. Overall, University A had followed up the sevenpointed star model. The stakeholder had committed to succession planning and management. All the academic and administration staff show a positive attitude toward the succession planning program implemented in University A. The executives, top managers, and staff should be committed to the concept of succession planning and must support the implementation of the plan (Keerio \& Ahmad, 2019).

Decision-makers should assess the present work requirements in key positions. This can be prepared by the potential candidate for further advancement as proposed by Rothwell (2005). The results showed that the strategic positions involved in succession planning in University A can be divide into three categories. The first category included the chancellor and the deputy chancellor. The second category included the dean, deputy dean, director, and head of the department, while the third category included the officer and professional with the designation or grade of 48 and above.

The high-performance staff must be selected for further advancement as proposed by Rothwell (2005). For University A, to be in the candidate pool list, the staff must reach high achievement in their annual evaluation appraisal. A formal criteria rating of succession planning in University A provided by Respondent B will be attached in the appendices. To fulfill the future requirement, training is necessary for those potential candidates. Both the AKEPT and the university will provide training to those who involved in the succession planning program. The main factor which influences the succession planning is the role of human resource development (Sambrook, 2005). Human resource capital is an essential element in succession planning and it is a must to improve it.

The organization should establish a process to assess future individual potential as proposed by Rothwell (2005). The potential for promotion to higher-level responsibilities should be considered as the backdrop of the future as mentioned by Rothwell (2005). University A uses the psychometric test and the dope personality to test the potential of a candidate. In the dope personality tests, the results showed that most of the strategically positioned staff belong to the eagle category because eagles have leadership traits such as being highly analytical and decisive. Further information about the dope personality will be attached in the appendices.

The organization must close the developmental gap between the internal and external candidates in the organization. In University A, the priority to fill in the key vacant position will only be given to the internal or existing staff, because the decision making position requires working experience. The possibility to find an outside candidate to fill in a vacant strategic position is very rare. The faculty member will always nominate their members to fill in the vacant key position. Internal promotions have the power to be more successful because there is more information available to make accurate decisions (Sheridan, Slocum, Buda, \& Thompson, 1990). Most of the key vacant positions will only be given to the existing staff, where the policy of University A prefers the promotion from within rather than recruitment from outside.

The organization must evaluate the succession planning program. Evaluation of the system and plan also must be considered in the human resources duties. The results show that succession planning in University A shows the space for improvement. Some improvement is already implemented. With the formation of integrity and succession planning division, the University A, succession planning will become better in the future. Link succession planning with other processes of talent management including is important (Aberdeen Group November, 2006; Bano, 2017).

\subsection{Recommendation}

The Ministry of Education is recommended to grant full autonomy to the higher education institutions for the implementation of succession planning. Higher education institutions with full autonomy will be more active and successful in implementing the program. Since this research only used a qualitative method, the mixed method including qualitative and quantitative research can be used which possibly provides expansive and useful information to the themes of research established. Future research on succession planning in higher education can be improved to get better research results as if the data collection can be expanded to all levels of management in University A, as compared to this research which was only covering the staff involved at the strategic position level.

\subsection{Conclusion}

In this study, the research objective and research question were developed and answered by the researcher. The final results further explained the process of succession planning in University A. Overall, the succession planning management in University A had followed up the seven-pointed model as proposed by Rothwell (2005). The sevenpointed model had ensured the process of identifying a management position at University A. As a closing, discussions were being made to explain the findings of this research. Suggestions and recommendations were also provided to higher education institutions and the methodology in conducting this research.

\section{References}

Aberdeen Group November. (2006). Succession planning strategies the right people, for the right jobs, at the right time American heritage ${ }^{\circledR}$ dictionary of the English language (5th ed.): Houghton Mifflin Harcourt Publishing Company.

Ahmad, A. R., \& Keerio, N. (2020). The critical success factors of succession planning in Malaysian public universities. International Journal of Advanced Science and Technology, 29(5), 4028-4040.

Bano, Y. (2017). A conceptual model of succession planning for public higher learning institutions in malaysia. Journal of Techno Social, 9(2), $79-85$.

Barden, D. M. (2009). Your next few leaders: The times have come for colleges and universities get serious about succession planning. The Chronicle of Higher Education. Retrieved from www.chronicle.com [June 8, 2009].

Braun, V., \& Clarke, V. (2013). Successful qualitative research: A practical guide for beginners. London: Sage.

Fancher, L. P. (2007). The influence of organizational culture on the implementation of succession planning. Dissertation, Georgia State University, 2007. Retrieved from https://scholarworks.gsu.edu/pmap_diss/28. 
Gonaim, F. A. (2019). Leadership in higher education in Saudi Arabia: Benefits, constraints and challenges of adopting servant leadership model by department chairs. International Journal of Education and Practice, 7(2), 101-111.Available at: https://doi.org/10.18488/journal.61.2019.72.101.111.

Jamye, L., Johnson, C., Faught, S., \& Street, J. (2013). The need to practice what we teach: Succession management in higher education. American Journal of Management, 13(2), 73-78.

Kamal, S. M. (2019). Developing EFL learners vocabulary by reading English comprehension in EFL classroom. International Journal of English Language and Literature Studies, 8(1), 28-35.Available at: https://doi.org/10.18488/journal.23.2019.81.28.35.

Keerio, N., \& Ahmad, A. R. (2019). The practices of succession planning in Malaysian public universities. Paper presented at the 33rd International Business Information Management Association Conference: Education Excellence and Innovation Management through Vision 2020, IBIMA 2019; Granada; Spain; 10 April 2019 through 11 April 2019.

Keller, K. (2018). Building the case for succession planning in higher education: A study of succession planning pilots within the minnesota state colleges and universities system. (2018). Culminating Projects in Higher Education Administration. 25. Retrieved from https://repository.stcloudstate.edu/hied_etds/25.

Miles, M. B., \& Huberman, A. M. (1994). Qualitative data analysis: An expanded sourcebook (2nd ed.). Thousand Oaks, CA: Sage.

Pitman, T. (2000). Perceptions of academics and students as customers: A survey of administrative staff in higher education. Journal of Higher Education Policy and Management, 22(2), 165-175.Available at: https://doi.org/10.1080/713678138.

Rao, H., \& Drazin, R. (2002). Overcoming resource constraints on product innovation by recruiting talent from rivals: A study of the mutual fund industry, 1986-1994. Academy of Management Journal, 45(3), 491-507.Available at: https://doi.org/10.5465/3069377.

Rothwell, W. J. (2005). Effective succession planning: Ensuring leadership continuity and building talent from within. New York: AMACOM.

Rothwell, W. J. (2005). Effective succssion planning: Ensuring continuity and building talent from within (3rd ed.): American Management Associatio (AMACOM).

Rothwell, W. (2010). Effective succession planning: Ensuring leadership continuity and building talent from within: Amacom.

Sambrook, S. (2005). Exploring succession planning in small, growing firms. Journal of Small Business and Enterprise Development, 12(4), 579594.Available at: https://doi.org/10.1108/14626000510628243.

Shadi, E. M., \& Noor, A. M. (2011). Identifying the important factors influencing the implementation of succession planning. Paper presented at the 2011 International Conference on Information and Finance IPEDR vol.21 (2011).

Sheridan, J. E., Slocum, J. J. W., Buda, R., \& Thompson, R. C. (1990). Effects of corporate sponsorship and departmental power on career tournaments. Academy of Management Journal, 33(3), 578-602.Available at: https://doi.org/10.5465/256582.

Thompsen, Joyce, A., \& Smith, A. E. P. (2006). Building leadership strength: Current trends in succession planning and management. The Catalyst ProQuest Education Journal, 35(2), 2-3. 